\title{
Krzysztof Stępnik, Wojny bałkańskie lat 1912-1913 w prasie polskiej. Korespondencje wojenne i komentarze polityczne, Wydawnictwo Uniwersytetu Marii Curie-Skłodowskiej, Lublin 2011, ss. 262 + ilust.
}

W roku bieżącym przypada okrągła, setna rocznica wybuchu wojen bałkańskich, rozgrywających się w latach 1912-1913. Mimo że miały one kluczowe znaczenie nie tylko dla dziejów Półwyspu Bałkańskiego, ale także całej Europy, nie są szerzej znane w Polsce. Fakt ten może budzić zdziwienie, ponieważ kontakty polsko-bałkańskie, w szerokim znaczeniu tego terminu, mają długą tradycję. Pomijając działania natury czysto politycznej polskich emisariuszy u progu wojny krymskiej, zwrócić należy uwagę na działalność takich postaci, jak między innymi Jan Grzegorzewski i słowianofile polscy, którzy na przełomie XIX i XX wieku propagowali wiedzę na temat Europy Południowo-Wschodniej, zwłaszcza w odniesieniu do bratnich narodów słowiańskich. Te relatywnie bliskie związki z Półwyspem Bałkańskim nie przełożyły się jednak na szerzej zakrojone badania naukowe w okresie późniejszym. Przyczyn takiego stanu rzeczy było wiele i nie czas tu i miejsce, by je szczegółowo analizować. Bezsprzecznie jednak stwierdzić należy, że w okresie międzywojennym, ale także i powojennym badania te prowadziło jedynie bardzo wąskie grono specjalistów, czego rezultatem jest stosunkowo niewielka liczba publikacji poświęconych dziejom tej części Starego Kontynentu i stan swoistej „niszowości” ogólnie rozumianej tematyki bałkańskiej.

Stąd też z dużym zadowoleniem powitać należy pojawienie się na rynku wydawniczym książki Krzysztofa Stępnika, która prezentuje ważny moment w dziejach Półwyspu Bałkańskiego i zamieszkujących go narodów. Nie tylko przybliża ona polskiemu czytelnikowi dynamiczne przemiany polityczne zachodzące na mapie Bałkanów w latach 1912-1913, ale także przynosi wiele cennych informacji stanowiących przyczynek do zrozumienia podstaw tychże przemian i współcześnie panujących stosunków na Bałkanach. W tym kontekście książka 
ta ma również niebagatelne znaczenie dla poszerzania wiedzy o tej części naszego kontynentu w szerszym, ogólnoeuropejskim wymiarze. Fakt, że część państw bałkańskich jest już obecnie naszymi partnerami w Unii Europejskiej, a kolejna grupa przygotowuje się do przystąpienia do tej struktury, powoduje swego rodzaju „głód wiedzy” coraz szerszych kręgów społecznych Wspólnoty, w tym także i w Polsce, na temat przeszłości tego regionu, a także relacji łączących ulokowane na jego obszarze kraje. Głód ten, przynajmniej w części, książka Krzysztofa Stępnika niewątpliwie zaspokaja. Jednocześnie warto podkreślić, że praca ta podejmuje tematykę praktycznie nieznaną polskiemu czytelnikowi. Wojny bałkańskie z lat 1912-1913 opisane zostały dotychczas, pomijając opracowanie Mieczysława Tantego poświęcone roli Rosji w tym konflikcie (M. Tanty, Rosja wobec wojen bałkańskich 1912-1913 roku, Warszawa 1970) oraz wydaną przez Bellonę w 2010 roku w cyklu „Historyczne Bitwy” krótką monografię autorstwa Roberta Rabki (R. Rabka, Bałkany 1912-1913, Warszawa 2010), która notabene pozostawia wiele do życzenia, w kilku zaledwie artykułach naukowych i przedstawione jako część szerszych opracowań. W tym miejscu koniecznie jednak należy podkreślić, że książka Krzysztofa Stępnika nie ma charakteru opracowania historycznego i nie jest monografią wydarzeń rozgrywających się na Półwyspie Bałkańskim w latach 1912 i 1913. Jej autor, wybitny polski teoretyk i historyk literatury, wojny bałkańskie uczynił bowiem jedynie tłem szerokich rozważań, a za główną ich oś uznać trzeba kwestie związane z teorią komunikowania masowego i zachowaniami politycznymi. Czyniąc podstawowym przedmiotem badań doniesienia prasy polskiej ilustrujące przebieg działań wojennych w Europie Południowo-Wschodniej na początku XX wieku, Stępnik stworzył dzieło interdyscyplinarne, łączące elementy historii, medioznawstwa, stosunków międzynarodowych, a nawet socjologii polityki. Tym samym wieloaspektowe spojrzenie na ważne wydarzenia natury politycznej sprawia, że jego praca jest ciekawą lekturą dla szerokich kręgów odbiorców i wnosi wiedzę do kilku dyscyplin naukowych.

Recenzowana książka składa się z dwóch zasadniczych części.

Pierwszą z nich autor poświęcił prezentacji zarówno treści, jak i struktury korespondencji wojennych publikowanych w polskich gazetach i periodykach. Warto podkreślić, że Krzysztof Stępnik skupił uwagę wyłącznie na doniesieniach polskich dziennikarzy, którzy, jak słusznie podkreślił już we wstępie, stawiali dopiero pierwsze kroki w trudnym zawodzie korespondenta wojennego. Mimo braku doświadczenia komentatorzy wysyłani przez redakcje polskich czasopism dobrze wypełniali swoje zadania, dostarczając czytelnikom wielu ciekawych informacji dotyczących zarówno relacjonowanych wydarzeń, jak i poszczególnych aspektów pracy korespondentów wojennych. Interesującym wątkiem odnoszącym się do tego drugiego obszaru, na który autor zwrócił uwagę w swej pracy, jest 
wszechobecna cenzura wojskowa i ściśle z nią powiązana propaganda państwowa. Jakkolwiek nie były to zabiegi obce okresowi wcześniejszemu, szczególne nasilenie tych praktyk nastąpiło właśnie w trakcie wojen bałkańskich, a korespondenci wojenni, siłą rzeczy, zmuszeni byli prezentować obraz wydarzeń korzystny dla tej strony konfliktu, która akredytowała ich przy swojej armii. Taki stan rzeczy wynikał ze świadomych zabiegów wszystkich stron konfliktu, które dbały o to, by dziennikarze nie mieli możliwości bezpośredniego oglądu sytuacji na linii frontu. Stąd też lokowano korespondentów z dala od działań wojennych, zmuszając ich do korzystania $z$ oficjalnych biuletynów wojskowych i dodatkowo skrupulatnie kontrolując treść przekazywanych przez nich depesz. Szczególnym aspektem tych działań, jak wykazuje autor, były także szeroko zakrojone akcje propagandowe, wyrażające się między innymi w organizowaniu - zwłaszcza przez Czarnogórców i Greków - swego rodzaju gier wojennych, w trakcie których żołnierze prowadzili ze sobą improwizowane walki, aby stworzyć odpowiedni obraz dla fotoreporterów chcących przekazać swoim redakcjom ciekawe materiały ikonograficzne. Jak nietrudno się domyślić, materiały te miały ukazywać bohaterstwo i zaangażowanie poszczególnych armii w bojach z wrogiem. Warto jednak podkreślić, że mimo tych działań przeważająca część korespondentów wojennych kreowała rzeczywisty obraz wydarzeń, a szczególnie cennym źródłem wiedzy na temat ówczesnych Bałkanów są ich relacje z szeroko rozumianego zaplecza frontu, ukazujące zarówno życie społeczne, jak i stereotypy na temat poszczególnych stron konfliktu. Zdecydowanie mniejszą wartość poznawczą mają natomiast przytaczane przez dziennikarzy relacje z pól bitewnych, które ze względów wskazanych powyżej nie mogą być samodzielnym źródłem historycznym, na co autor słusznie kilkakrotnie zwraca uwagę.

W drugiej części książki Krzysztof Stępnik zaprezentował wybrane komentarze polityczne pojawiające się na przełomie 1912 i 1913 roku. Idea ta wydaje się niezwykle trafna. Wojny bałkańskie stały się bowiem nie tylko atrakcyjnym „widowiskiem medialnym”, które z zainteresowaniem obserwowały szerokie kręgi społeczeństwa europejskiego, ale także bazą do szerszych rozważań na temat ich potencjalnych konsekwencji i przeszłości całego kontynentu. Dotyczące tych zagadnień dyskusje koncentrowały się w polskiej rzeczywistości przede wszystkim na tzw. sprawie polskiej, a więc kwestii odzyskania niepodległości. Taki stan rzeczy podyktowany był w dużej mierze stałym wzrostem napięcia pomiędzy dwoma blokami militarno-politycznymi wielkich mocarstw, które już w 1908 roku groziło wybuchem konfliktu zbrojnego. Tym samym sytuacja ta motywowała polskich myślicieli i publicystów do oceny ewentualnych skutków starcia pomiędzy państwami zaborczymi, a zwłaszcza Rosją i Austro-Węgrami. Szczególnie często kwestie te analizowali członkowie krakowskiego 
Klubu Słowiańskiego, którzy wyniki swoich obserwacji publikowali na łamach miesięcznika „Świat Słowiański”. Nie ulega wątpliwości, że analizowane przez Krzysztofa Stępnika artykuły Feliksa Konecznego i Zdzisława Maryckiego stanowią kwintesencję poglądów tego środowiska na sytuację międzynarodową w Europie na początku XX wieku. Jednocześnie Klub Słowiański stawiał sobie ambitny cel zaznajomienia szerszych kręgów polskiego społeczeństwa z historią i dorobkiem dziejowym narodów słowiańskich, starając się jednocześnie ściśle wiązać kwestie słowiańskie z kwestią polską. Trudno zatem się dziwić, że tak istotne wydarzenie jak wojny bałkańskie zwróciło ich uwagę, a doniosłość zmian, jakie pociągały za sobą dla ówczesnej geopolityki oraz stosunków międzynarodowych i militarnych, skłaniały ich do głębokich przemyśleń na ten temat. Warto jednak podkreślić, że Stępnik nie ograniczył się wyłącznie do prezentacji galicyjskiego punktu widzenia. W swej dogłębnej analizie komentarzy politycznych na temat rozgrywających się w latach 1912-1913 wydarzeń na Bałkanach dał bowiem szeroki obraz poglądów, które reprezentowała polska prasa ukazująca się na terenie zaboru rosyjskiego, jakże odmiennych od wizji słowianofilów krakowskich. $\mathrm{Na}$ uwagę zasługuje również fakt, że autor poddał wnikliwej analizie kilkadziesiąt tytułów prasowych. Dzięki temu zaprezentowany przez niego obraz polskich reminiscencji wojen bałkańskich jest niezwykle bogaty, co w efekcie pozwala czytelnikowi zapoznać się zarówno ze specyfiką bałkańską, dając dobre podstawy do zrozumienia procesów zachodzących współcześnie w tej części Europy, jak i z poglądami ówczesnych kręgów społecznych i politycznych.

Na zakończenie wypada odnieść się do języka i stylistyki pracy Krzysztofa Stępnika. Jednoznacznie należy podkreślić, że praca została napisana $\mathrm{z}$ wielką pieczołowitością i poprawnością językową, a tym samym służyć może za wzór godny naśladowania.

Reasumując powyższe rozważania, trzeba jeszcze raz zwrócić uwagę na fakt, że na polskim rynku wydawniczym pojawiła się niezwykle cenna pozycja, która nie tylko w sposób niekonwencjonalny i zarazem w pełni profesjonalny przekazuje czytelnikowi szeroką wiedzę na temat wydarzeń zachodzących na Półwyspie Bałkańskim, lecz jednocześnie piętnuje stereotypy i uprzedzenia nadal mocno zakorzenione w polskim społeczeństwie w stosunku do narodów bałkańskich, a także przystępnie prezentuje poglądy i koncepcje polskich kręgów politycznych na początku XX wieku. Tym samym praca ta zasługuje na uwagę nie tylko studentów dziennikarstwa czy politologii, ale też wszystkich tych, którzy interesują się przeszłością Europy Południowo-Wschodniej. 